\title{
Sosialisasi Peranan Profesi Aktuaris pada Industri Asuransi dan Asuransi untuk Kehidupan kepada Masyarakat Cikarang
}

\author{
Maria Yus Trinity Irsan'), Fauziah Nur Fahirah Sudding2), Lina Rosmawati3) \\ 1), 2, 3) Fakultas Bisnis, Universitas Presiden, \\ 1) maria.irsan@president.ac.id \\ 2) fauziahfahirah@president.ac.id
}

\begin{abstract}
ABSTRAK
Program Studi Aktuaria adalah program studi baru di Indonesia. Beberapa tahun belakangan ini perguruan tinggi negeri maupun swasta berlomba untuk membuka program studi ini. Kekurangan profesi aktuaris di Indonesia menjadi salah satu alasan perlu adanya program studi ini di universitas di Indonesia. Namun, masih banyak masyarakat Indonesia yang masih asing dan belum mengenal profesi aktuaris dan bidang ilmu aktuaria yang merupakan cabang dari bidang ilmu matematika. Selain itu, industri asuransi yang sangat erat kaitannya dengan keprofesian aktuaris juga belum banyak diketahui manfaat dan peranannya dalam kehidupan. Kegiatan sosialisasi yang dilakukan dengan membagikan brosur dan menjelaskannya kepada masyarakat ditujukan untuk memberikan pengetahuan kepada masyarakat khususnya masyarakat Cikarang tentang profesi aktuaria, meningkatkan kesadaran masyarakat akan pentingnya asuransi, serta mensosialisasikan hubungan antara asuransi dan profesi aktuaria.
\end{abstract}

Kata-kata kunci: aktuaris, aktuaria, asuransi

\section{ABSTRACT}

Actuarial science study program is a new study program in Indonesia. Recently some universities in Indonesia have opened this study program. Currently, Indonesia needs more actuary, this is one of the reasons for the existence of the actuarial science study program in Indonesia. However, many Indonesians do not know about the actuary and actuarial science field. Besides that, most Indonesians have not realized the importance of insurance for life. The socialization about actuary and insurance is one of the ways to introduce actuary and increase the insurance awareness to the people in Indonesia, especially in Cikarang. This event went by distributing pamphlet and giving a short explanation to the respondent about actuary, insurance, and the relationship between them.

Keywords: actuary, actuarial science, insurance

\section{PENDAHULUAN}

Asuransi atau pertanggungan adalah suatu perjanjian yang dibuat oleh dua belah pihak, satu pihak disebut tertanggung dan pihak lain disebut sebagai penanggung. Pihak tertanggung berkewajiban untuk membayar iuran atau premi secara berkala dalam periode waktu tertentu kepada pihak penanggung. Disisi lain, pihak penanggung berkewajiban untuk memberikan jaminan finansial kepada pihak tertanggung jika terjadi sesuatu yang menimpa pihak tertanggung dan menimbulkan kerugian finansial sesuai dengan kesepakatan yang telah disepakati bersama (OJK).

Berdasarkan definisi asuransi di atas dapat diketahui bahwa asuransi sangat bermanfaat dalam rangka untuk menanggulangi risiko keuangan yang mungkin terjadi di masa depan. Oleh karena itu, peranan asuransi dalam berbagai unit bisnis maupun kehidupan pribadi menjadi penting. 
Dalam menentukan risiko keuangan dan premi yang harus dibayarkan oleh pihak tertanggung, pihak penanggung menggunakan ilmu aktuaria. Ilmu aktuaria sendiri terdiri dari beberapa ilmu, yaitu matematika, statistika, keuangan, ekonomi, dan juga ilmu komputer. Kombinasi ilmu ini digunakan untuk memprediksi risiko keuangan yang akan terjadi di masa depan, tentang kapan dan bagaimana kejadian tersebut akan terjadi. Dengan demikian, ilmu aktuaria memiliki peranan yang penting dalam industry asuransi. Seseorang yang ahli dalam bidang ilmu aktuaria disebut sebagai seorang aktuaris ((PAI)).

Berdasarkan (AAUI, 2019), industri asuransi menguasai sebesar 53\% dari total keselurahan asset Industri Keuangan Non-Bank (IKBN), pada halaman yang sama dijelaskan bahwa industri asuransi memiliki potensi untuk tumbuh dan berkembang untuk waktu ke depan. Namun, perkembangan ini tidak diikuti oleh pertumbuhan aktuaris di Indonesia. Pertumbuhan aktuarias di Indonesia dapat dilihat pada Gambar 1 (Arie Munandar, 2018)

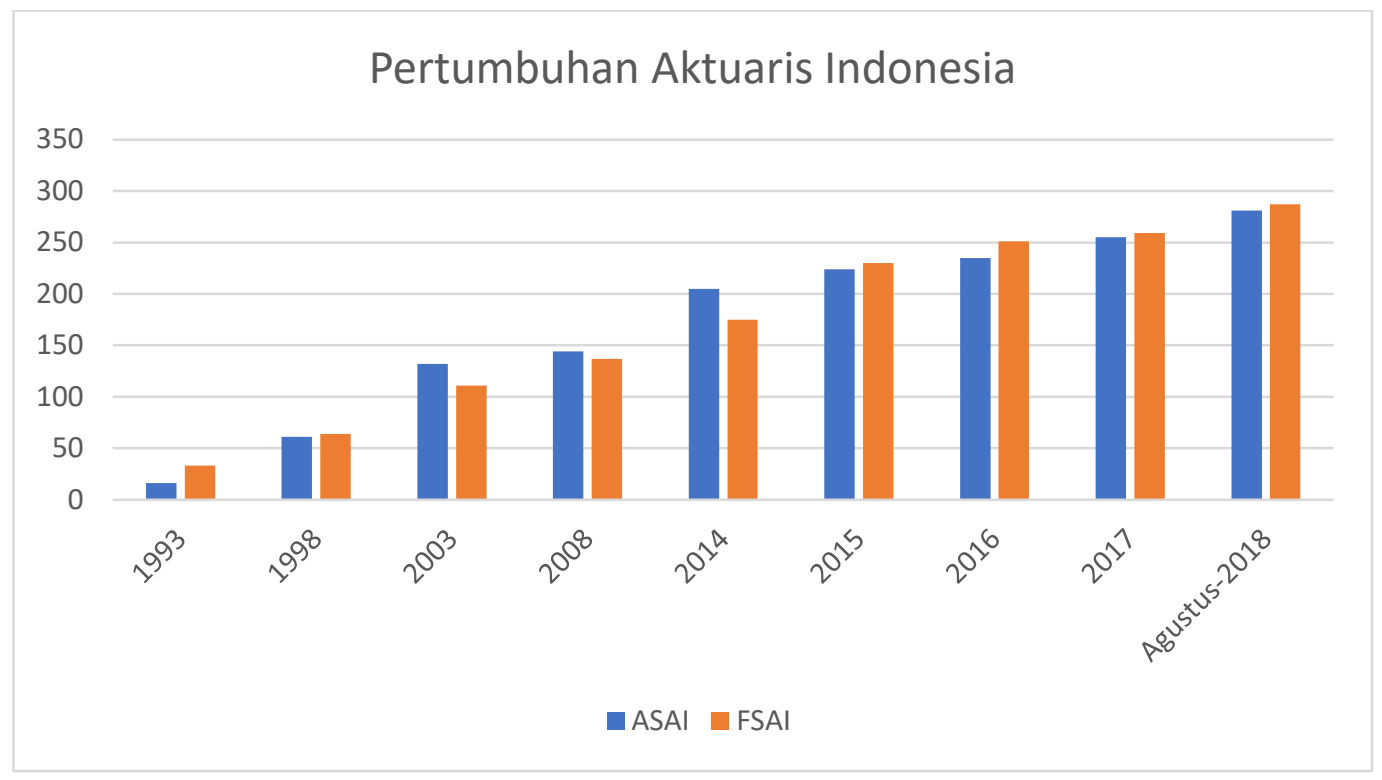

Gambar 1. Pertumbuhan Aktuaris di Indonesia

Selain itu, kesadaran akan pentingnya asuransi masih sangat rendah pada kalangan menengah kebawah masyarakat Indonesia. Hal ini ditunjukkan oleh masih sedikitnya masyarakat Indonesia yang menggunakan asuransi. Berdasarkan (Astuti, 2018) hanya 1.7\% dari penduduk Indonesia yang miliki asuransi.

Menyikapi masih kurangnya pengetahuan masyarakat Indonesia akan profesi aktuaris juga akan pentingnya asuransi pada kehidupan, maka perlu dilakukan sosialisasi peranan profesi aktuaris pada industri asuransi serta pentingnya asuransi bagi kehidupan. Sosialisasi ini ditujukan bagi masyrakat Indonesia, secara khusus masyarakat yang tinggal di daerah Cikarang. 


\section{METODE PELAKSANAAN}

Kegiatan sosialisasi peranan asuransi dan aktuaris ini dilaksanakan dalam bentuk membagikan brosur berisikan informasi peranan dan fungsi asuransi serta profesi aktuaris kepada masyarakat. Kegiatan ini berlangsung pada tanggal 7 April 2019, bertempat di Taman Sehati Cikarang. Kegiatan ini dilaksanakan pada sore hari, yaitu pada pukul 16.30 18.00.

Selain membagikan brosur kepada masyarakat yang sedang berada di Taman Sehati Cikarang, juga diberikan penjelasan lisan singkat kepada masyarakat tentang setiap informasi yang disajikan dalam brosur tersebut. Adapun informasi yang disajikan pada brosur tersebut adalah keahlian aktuaris, definisi, mekanisme, tahapan bisnis asuransi jiwa, keuntungan asuransi jiwa, hubungan antara asuransi dan ilmu aktuaria, serta jenis-jenis asuransi. Pelaksana kegiatan adalah dosen dan mahasiswa Program Studi Aktuaria, Universitas Presiden. Jadwal kegiatan sosialisasi disajikan pada Tabel 1.

\section{Tabel 1}

Jadwal Rangkaian Kegiatan Sosialisasi

\begin{tabular}{|l|c|c|c|c|c|c|}
\hline \multirow{2}{*}{ Kegiatan } & \multicolumn{5}{c|}{ Maret 2019 } & \multicolumn{2}{c|}{ April 2019} \\
\cline { 2 - 7 } & \multicolumn{5}{c|}{ Minggu ke } \\
\cline { 2 - 7 } & $\mathbf{1}$ & $\mathbf{2}$ & $\mathbf{3}$ & $\mathbf{4}$ & $\mathbf{1}$ & $\mathbf{2}$ \\
\hline Survei beberapa lokasi kegiatan & & & & & & \\
\hline $\begin{array}{l}\text { Penetapan lokasi kegiatan dan survei } \\
\text { lapangan }\end{array}$ & & & & & & \\
\hline $\begin{array}{l}\text { Pembuatan materi brosur dan } \\
\text { pencetakan brosur }\end{array}$ & & & & & & \\
\hline Pelaksanaan kegiatan sosialisasi & & & & & & \\
\hline Penyusunan laporan kegiatan & & & & & & \\
\hline
\end{tabular}

\section{HASIL DAN PEMBAHASAN}

Dalam pelaksanaan sosialisasi tentang profesi aktuaris dan asuransi, terdapat 50 (lima puluh) brosur yang telah dibagikan dan dijelaskan kepada masyarakat Cikarang. Informasi yang termuat dalam brosur tersebut adalah sebagai berikut:

\section{a. Keahlian seorang aktuaris di Indonesia}

Keahlian seorang aktuaris adalah sebagai berikut:

1) Memahami perjanjian asuransi dan kependudukan

2) Menyusun dan memahami masalah asuransi 
3) Menentukan surrender value dan loan of policies

4) Menggunakan aplikasi computer yang relavan dengan tugas aktuaris

5) Memahami proses penyusunan tabel mortalitas

6) Berkomunikasi aktif dengan Bahasa Indonesia maupun bahasa asing

\section{b. Hubungan asuransi dan aktuaris}

Aktuaria adalah cabang ilmu matematika terapan dengan kombinasi dengan berbagai ilmu lainnya seperti statistik, kalkulus, sistem numerik hingga aplikasi IT. Seorang aktuaris adalah seseorang yang ahli dalam bidang ilmu aktuaria dan telah melulusi ujian sertifikasi oleh asosiasi aktuaris. Di Indonesia ujian profesi aktuaris diselenggarakan oleh Persatuan Aktuaris Indonesia. Dalam melakukan perhitungan prediksi risiko keuangan, perhitungan premi, perhitungan cadangan, dll, asuransi menggunakan ilmu aktuaria. Oleh karena itu, asuransi merupakan industri yang paling banyak menggunakan aktuaris.

\section{c. Jenis-jenis asuransi}

Ada dua jenis asuransi yaitu asuransi jiwa dan asuransi umum. Asuransi umum terdiri dari semua jenis asuransi yang bukan asuransi jiwa, misalnya asuransi kesehatan, asuransi pendidikan, asuransi kendaraan, asuransi pertanian, dan lainnya.

\section{d. Definisi Asuransi Jiwa.}

Asuransi Jiwa adalah program perlindungan dalam bentuk pengalihan risiko ekonomis atas meninggal atau hidupnya seseorang yang dipertanggungkan.

\section{e. Mekanisme asuransi}

Mekanisme asuransi disajikan pada Gambar 2 (AAJI). 
orang-orang menghadapi risiko yang sama sepakat untuk mengumpulkan sejumlah dana (premi) untuk disimpan dan dikelola oleh asuransi

\section{Gambar 2. Mekanisme Asuransi}

1) Tahapan bisnis asuransi adalah:

(a) Menyatukan orang-orang dengan kepentingan asuransi yang sama dengan tujuan untuk membagi risiko yang sama

(b) Mengumpulkan dana (premi) dari sekumpulan orang yang telah disatukan tadi

(c) Membayar klaim kepada mereka yang menderita kerugian.

2) Keuntungan asuransi

(a) Menawarkan pilihan investasi yang aman

(b) Mendorong untuk menghemat

(c) Membebaskan diri dari rasa khawatir mengenai masalah keuangan di masa depan

(d) Menjaga pada saat usia lanjut.

Penjelasan di atas disajikan dalam bentuk brosur sebagai berikut (Gambar 3).
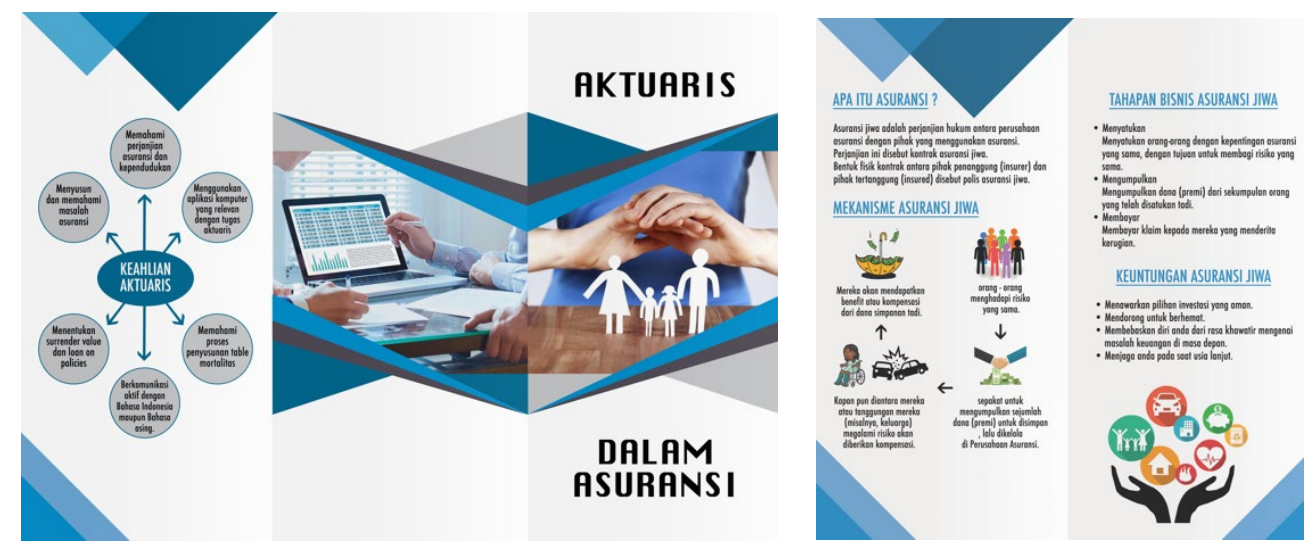

APA HUBUNGAN SUURANII DENGAN
AKIURRA?
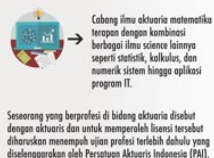

JENIS - JENIS ASURANSI

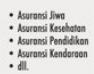

Gambar 3. Brosur Kegiatan Sosialisasi 
Tim membagikan 50 brosur dan dan memberikan penjelasan kepada masyarakat tentang isi brosur dan informasi yang terkait dengan asuransi dan profesi aktuaris. Berdasarkan kegiatan yang telah dilaksanakan, diperoleh bahwa pengetahuan masyarakat masih sangat minim tentang profesi aktuaris dan asuransi. Terdapat sekitar 90\% masyarakat yang tidak mengetahui tentang profesi aktuaris, sementara $10 \%$ diantaranya pernah mendengar namun tidak begitu memahami profesi ini, bidang keahlian dan juga bidang ilmunya. Dilain sisi, ketika ditanya dan dijelaskan mengenai asuransi, semua masyarakat yang menjadi responden mengetahui tentang asuransi namun tidak mengetahuinya secara mendalam. Responden mengetahui asuransi sebagai media yang membantu pada waktu sakit ataupun pada kendaraan. $70 \%$ dari responden masih belum memiliki kertertarikan untuk memiliki asuransi selain asuransi kesehatan yang disubsidi oleh pemerintah dengan alasan bahwa hal tersebut belum menjadi prioritas utama mereka setelah kebutuhan pokok.

Pada saat ini Indonesia kekurangan tenaga aktuaris. Seperti yang terlihat pada Gambar 1, pada tahun 2018 tenaga aktuaris yang terdaftar di Persatuan Aktuaris Indonesia (PAI) hanya 568 orang sudah termasuk Associate Societies Actuary Indonesia (ASAI) dan Fellow Societies Actuary Indonesia (FSAI). Dengan kondisi seperti ini, pengetahuan akan profesi aktuaris dan ilmu akturia perlu disosialisasikan kepada seluruh masyarakat Indonesia.

Selain itu, kesadaran akan pentingnya asuransi dalam kehidupan juga perlu disosialisasikan kepada masyarakat. Pengetahuan tentang asuransi yang tidak hanya berguna untuk kesehatan saja, tetapi dalam beberapa sektor lainnya seperti pendidikan, bisnis, dan lainnya.

\section{KESIMPULAN}

Berdasarkan kegiatan yang telah dilaksanakan, disimpulkan bahwa masyarakat Cikarang masih memiliki pengetahuan yang kurang terhadap profesi aktuaris serta masih kurangnya keinginan untuk memiliki asuransi non-subsidi. Melalui kegiatan sosialisasi profesi aktuaris dan asuransi pada masyarakat Cikarang, masyarakat telah diberikan penjelasan mengenai profesi aktuaris, asuransi dan hubungan keduanya, sehingga dengan demikian diharapkan masyarakat dapat lebih memahami lebih dalam terhadap kedua hal tersebut. 


\section{REFERENSI}

PAI. (t.thn.). Siapa Aktuaris? Diunduh dari https://www.aktuaris.or.id/page/content/4/siapaitu-aktuaris

AAJI. (t.thn.). Asosiasi Asuransi Jiwa Indonesia. Diunduh dari https://www.aaji.or.id/File/Download/491

AAUI. (2019, March 14). OJK targetkan industri asuransi tumbuh 15\% di 2019. Diunduh dari https://aaui.or.id/ojk-targetkan-industri-asuransi-tumbuh-15-persen-di-2019/

Arie Munandar, F. (2018). Kebutuhan Profesi Aktuaria dalam Industri Keuangan. Seminar Nasional: Aktuaria di Era Industri 4.0. Jakarta: READI.

Astuti, R. (2018, November 17). Baru 17\% penduduk Indonesia yang miliki asuransi. Diunduh dari https://ekonomi.kompas.com/read/2018/11/17/200454426/baru-17persen-penduduk-indonesia-yang-miliki-asuransi

OJK, (t.thn.). IKNB Asuransi. Diunduh dari https://www.ojk.go.id/id/kanal/iknb/Pages/Asuransi.aspx 